\title{
Red cell aplasia following prolonged D-penicillamine therapy
}

\author{
J. L. GOLLAN, SONAY HUSSEIN, A. V. HOFFBRAND, AND SHEILA SHERLOCK
}

From the Departments of Medicine and Haematology, The Royal Free Hospital, Pond Street, Hampstead NW3 2QG

SYNOPSIS Red cell aplasia developed in a case of Wilson's disease following an increase in Dpenicillamine dosage after 14 years' treatment. In vitro study of the effect of D-penicillamine on ${ }^{59} \mathrm{Fe}$ incorporation by marrow cells did not suggest that the patient's erythropoiesis was particularly sensitive to D-penicillamine or determine the mechanism of drug toxicity. However, three weeks after the drug was withdrawn, evidence of marrow regeneration was apparent, and within 10 weeks the haemoglobin had returned to normal. The patient has subsequently remained asymptomatic on an alternative chelating agent, triethylenetetramine dihydrochloride.

Since Walshe (1956) first demonstrated the ability of D-penicillamine to promote the urinary excretion of copper in Wilson's disease, the drug has found a variety of therapeutic applications. With its value in rheumatoid arthritis recently established and studies in chronic active liver disease in progress a renewed interest in the drug has been stimulated. Adverse haematological effects of D-penicillamine, such as thrombocytopenia and neutropenia, occur frequently, and an aplastic anaemia may rarely develop. Selective suppression of the erythroid series has, to our knowledge, not previously been observed. We report here the development of a reversible red cell aplasia in a case of Wilson's disease after 14 years' D-penicillamine therapy.

\section{Case Report and Investigations}

In 1954 at the age of 4 years hepatosplenomegaly was observed during the course of a transient febrile illness. A liver biopsy was performed and reported as showing almost normal histology. In 1960 the patient developed jaundice with ascites and a mild anaemia. An open liver biopsy on this occasion revealed established cirrhosis. Wilson's disease was diagnosed by the presence of Kayser-Fleischer rings and by the family history of a brother who had died at the age of 10 years with cirrhosis. Urinary copper excretion was $280 \mu \mathrm{g} / 24 \mathrm{~h}$ (normal $<70 \mu \mathrm{g} / 24 \mathrm{~h}$ ) but the serum copper and caeruloplasmin concentrations were normal. Treatment with D-penicillamine

Received for publication 8 September 1975
$\mathrm{HCl}$ was initiated in a dose of $0.9 \mathrm{~g}$ daily with gradual resolution of the jaundice and ascites.

By 1965 (aged 15), the patient was asymptomatic, still with prominent Kayser-Fleischer rings and minimal hepatosplenomegaly, but with no features of chronic liver disease or abnormal neurological signs. The haemoglobin level was $14.0 \mathrm{~g} / \mathrm{dl}$ and conventional liver function tests were normal. Several small opaque gallstones were observed on the abdominal $x$-ray. Hepatic biopsy showed an inactive cirrhosis with mild fat infiltration and a liver copper concentration of $620 \mu \mathrm{g} / \mathrm{g}$ dry weight (normal $<55$ $\mu \mathrm{g} / \mathrm{g}$ ). The urinary excretion of copper was 1500 $2000 \mu \mathrm{g} / 24 \mathrm{~h}$ on $0.9 \mathrm{~g}$ D-penicillamine daily. Two years later the dose was increased to $1.8 \mathrm{~g}$ daily and urinary copper excretion rose to $2300-2800 \mu \mathrm{g} / 24 \mathrm{~h}$.

The serum caeruloplasmin on this occasion had fallen to $7.2 \mathrm{mg} / \mathrm{dl}$ (normal $>20 \mathrm{mg} / \mathrm{dl}$ ). In 1968 , she became pregnant but developed pre-eclamptic toxaemia, and intrauterine death resulted at the 12th week. Although D-penicillamine therapy was maintained throughout the pregnancy no fetal abnormalities were noted. A live male baby was born by Caesarean section in 1970, but in the following year a further pregnancy was terminated due to toxaemia, and a tubal ligation was performed.

In 1973, after 13 years of chelation therapy, the haemoglobin level was $14.2 \mathrm{~g} / \mathrm{dl}$ with the red cell indices, total white cell and platelet counts normal. The urinary copper excretion on $1.2 \mathrm{~g}$ D-penicillamine $\mathrm{HCl}$ had diminished to $300-550 \mu \mathrm{g} / 24 \mathrm{~h}$, and the Kayser-Fleischer rings were still visible on slitlamp examination. In view of these findings, treat- 
ment was changed to $2.0 \mathrm{~g}$ D-penicillamine base daily and the urinary copper clearance was increased to $800-1200 \mu \mathrm{g} / 24 \mathrm{~h}$. Four months later the patient was admitted to hospital with a history of increasing lethargy, exertional dyspnoea, and giddiness of six weeks' duration. The haemoglobin concentration was $4.0 \mathrm{~g} / \mathrm{dl}$ (figure) with $2 \%$ reticulocytes. The red cells were macrocytic with moderate poikilocytosis and some oval cells and a MCV of $106 \mathrm{fl}$; white cells and platelets were normal. The faeces were negative for occult blood and there was no evidence of blood loss from other sources. A ${ }^{51} \mathrm{Cr}$-labelled red cell survival time was normal, with a negative Coombs' test and antinuclear factor, and a serum copper concentration of $5 \mu \mathrm{g} / \mathrm{dl}$ (normal 80-150 $\mu \mathrm{g} / \mathrm{dl}$ ). An assay for the measurement of plasma D-penicillamine level was not available at this time. The serum and red cell folate and serum vitamin $B_{12}$ levels were normal with negative parietal cell and intrinsic factor antibody tests. Ham's test was negative. Pyridoxine deficiency was excluded by the measurement of urinary xanthurenic and kynurenic acid excretion before and after a tryptophan load, The results were normal. The serum zinc concentration was normal $(125 \mu \mathrm{g} / \mathrm{dl})$. Sternal bone marrow biopsy showed normal cellularity with an $M: E$ ratio of $4: 1$. Granu-

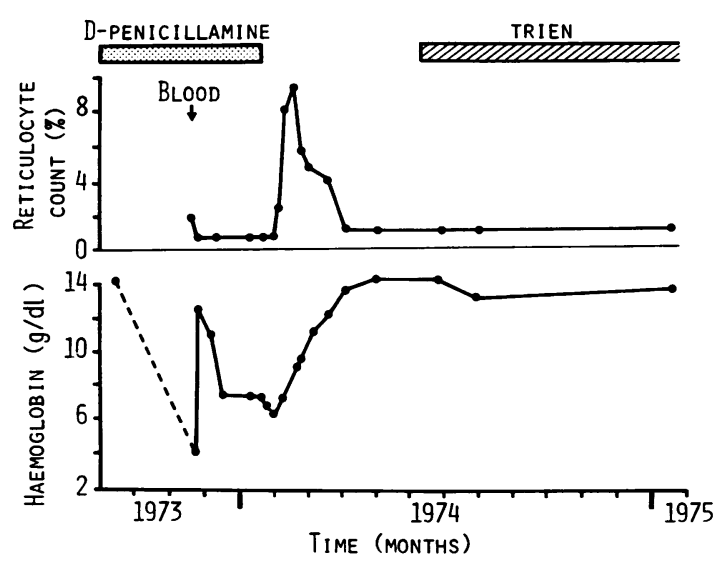

Figure Haemoglobin concentration and reticulocyte count in relation to drug therapy. lopoiesis and megakaryocytes were normal. Erythropoiesis was normoblastic and some of the inter- $\underline{\overrightarrow{0}}$ mediate and late normoblasts showed nuclear distortion and karyorrhexis and a few contained Howell- $\stackrel{\vec{S}}{\rightarrow}$ Jolly bodies. Iron stores were increased but no ring $\overrightarrow{0}$ sideroblasts were present. Liver function tests and 들 clotting studies were normal. The hepatic copper $\frac{\bar{\sigma}}{\sigma}$ concentration had decreased to $188 \mu \mathrm{g} / \mathrm{g}$ dry weight. $\stackrel{\nabla}{\circ}$ The serum immunoglobulins were normal apart from an IgA level of $32 \mathrm{mg} / \mathrm{dl}$ (normal 100-450 $\mathrm{mg} / \mathrm{dl}$ ). The patient was transfused 7 units of packed cells and was discharged from hospital with a $\vec{\omega}$ haemoglobin of $12.4 \mathrm{~g} / \mathrm{dl}$ (figure) on $2.0 \mathrm{~g} \mathrm{D}$ - $\stackrel{\omega}{\circ}$ penicillamine base and $100 \mathrm{mg}$ pyridoxine daily.

The symptoms of anaemia returned, and eight is weeks after transfusion the haemoglobin was 6.8 i $\mathrm{g} / \mathrm{dl}$ with an absolute reticulocyte count of $0.2 \%$ and $\vec{\omega}$ a normal white cell and platelet count. A further $w$ sternal marrow examination showed no significant $?$ change.

\section{SPECIAL STUDIES}

In vitro bone marrow colony growth in agar-gel medium was carried out according to Pike and 2 Robinson (1970) with and without addition of D- $\vec{\varphi}$ penicillamine $\mathrm{HCl}$ and D-penicillamine base. Bora oे marrow was incubated with D-penicillamine for 15 $h$ before it was washed and cultured. There was no evidence of in vitro suppression of leucopoiesis by D-penicillamine $\mathrm{HCl}$ or D-penicillamine base (table I).

The in vitro effect of D-penicillamine on haem synthesis by marrow cells was studied by measuring ${ }^{59} \mathrm{Fe}$ uptake for haem synthesis by marrow erythroblasts (Krantz et al, 1963). Marrow was obtained from the patient and from a healthy volunteer. The patient's plasma and normal ABO compatible plasma were used in the culture of the patient's marrow cells. The volunteer's plasma and $\mathrm{ABO} 3$ compatible plasma were used for culturing the volunteer's marrow cells. Each test was done with and without addition of D-penicillamine base.을 There was inhibition by $\mathrm{D}$-penicillamine of ${ }^{59} \mathrm{Fe} D$ incorporation into the patient's marrow erythroblast haem, but similar inhibition was observed in the N normal control marrow erythroblasts (table II). Also there was no evidence that the patient's plasma

\begin{tabular}{|c|c|c|}
\hline Material & Colonies/8 $\times 10^{4}$ Nucleated Cells & Colony-forming Units in Culture $/ 1$ × \\
\hline \multirow{3}{*}{$\begin{array}{l}\text { Bone marrow and saline } \\
\text { Bone marrow }+ \text { D-penicillamine base }(50 \mu \mathrm{g} / \mathrm{ml} \text { of } \\
\text { marrow) } \\
\text { Bone marrow }+ \text { D-penicillamine } \mathrm{HCl}(50 \mu \mathrm{g} / \mathrm{ml} \text { of } \\
\text { marrow) }\end{array}$} & $22 \cdot 0$ & 275 \\
\hline & $17 \cdot 4$ & 217 \\
\hline & 18.4 & 230 \\
\hline
\end{tabular}




\begin{tabular}{|c|c|c|c|c|}
\hline \multirow[t]{2}{*}{ D-Penicillamine Base } & \multicolumn{3}{|c|}{ Counts/minute } & \multirow[t]{2}{*}{ Plasma } \\
\hline & "'Fe Total & "Fe in Haem & $" \mathrm{Fe}$ in Protein & \\
\hline $\begin{array}{l}\text { Without } \\
\text { With }(50 \mu \mathrm{g} / \mathrm{ml} \text { of culture) }\end{array}$ & 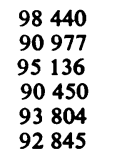 & $\begin{array}{r}308 \\
138 \\
174 \\
21 \\
32 \\
31\end{array}$ & $\begin{array}{c}586 \\
325 \\
366 \\
107 \\
172 \\
254\end{array}$ & Patient's \\
\hline $\begin{array}{l}\text { Without } \\
\text { With }(50 \mu \mathrm{g} / \mathrm{ml} \text { of culture) }\end{array}$ & 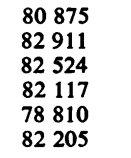 & $\begin{array}{r}109 \\
115 \\
98 \\
30 \\
29 \\
29\end{array}$ & $\begin{array}{r}192 \\
189 \\
204 \\
174 \\
89 \\
108\end{array}$ & ABO compatible \\
\hline $\begin{array}{l}\text { Without } \\
\text { With }(50 \mu \mathrm{g} / \mathrm{ml} \text { of culture) }\end{array}$ & $\begin{array}{r}97178 \\
99400 \\
102248 \\
100606 \\
101265\end{array}$ & $\begin{array}{r}118 \\
139 \\
142 \\
28 \\
27\end{array}$ & $\begin{array}{r}239 \\
241 \\
255 \\
71 \\
61\end{array}$ & Volunteer's \\
\hline $\begin{array}{l}\text { Without } \\
\text { With }(50 \mu \mathrm{g} / \mathrm{ml} \text { of culture) }\end{array}$ & $\begin{array}{l}93222 \\
96701 \\
98072\end{array}$ & $\begin{array}{r}118 \\
100 \\
26\end{array}$ & $\begin{array}{r}228 \\
207 \\
75\end{array}$ & \} ABO compatible \\
\hline
\end{tabular}

Table II Effect of D-penicillamine on ${ }^{59} \mathrm{Fe}$ uptake in vitro by bone marrow cells

contained an antibody or other inhibitory factor to haem synthesis in her own marrow.

Transformation of the patient's lymphocytes, assessed by ${ }^{3} \mathrm{H}$-thymidine uptake with phytohaemagglutinin (PHA) (Das and Hoffbrand, 1970), was much less than in a normal control but on addition of D-penicillamine base there was comparable inhibition of ${ }^{3} \mathbf{H}$-thymidine uptake into the patient's and control lymphocytes. There was no evidence that D-penicillamine base itself caused transformation of the patient's lymphocytes assessed morphologically and by ${ }^{3} \mathrm{H}$-thymidine uptake (table III).

Although these in vitro studies did not suggest that the patient's haemopoietic tissues were particularly susceptible to D-penicillamine, the drug was discontinued. Over the ensuing two weeks the haemoglobin concentration stabilized, and during the third week a reticulocyte response became evident (figure). This continued until 10 weeks later when the haemoglobin reached normal levels $(13.6 \mathrm{~g} / \mathrm{dl})$.

Chelation therapy was discontinued for a total of 14 weeks during which time the patient remained asymptomatic with normal liver function tests and

\begin{tabular}{lccl}
\hline & \multicolumn{3}{c}{ 'H-Thymidine Uptake/10" Cells (counts/min) } \\
\cline { 2 - 4 } & $-P H A$ & + PHA & $\begin{array}{l}+ \text { D-Penicillamine } \\
\text { Base } \\
(50 \mu g / m l \text { culture })\end{array}$ \\
\hline Patient & 92 & 482 & 163 \\
Control & 162 & 8412 & 177
\end{tabular}

Table III Lymphocyte transformation with PHA and D-penicillamine a urinary copper concentration repeatedly in the normal range $(14-45 \mu \mathrm{g} / 24 \mathrm{~h})$. In view of the potential hazard of a permanent red cell aplasia, which may have been induced by the reintroduction of $D$ penicillamine, in June 1974, treatment was begun with the alternative chelating agent, triethylenetetramine dihydrochloride (Trien). The drug was prepared by the procedure of Dixon et al (1972) and was introduced over a four-week period to an optimum dose of $1.6 \mathrm{~g}$ daily. This produced an inital urinary copper excretion of $600 \mu \mathrm{g} / 24 \mathrm{~h}$ which subsequently has been maintained at approximately $300 \mu \mathrm{g} / 24 \mathrm{~h}$. Urinary iron excretion has remained normal on triethylenetetramine dihydrochloride (less than 5 $\mu \mathrm{g} / 24 \mathrm{~h}$ ). Currently the patient is asymptomatic with a normal haemoglobin concentration. The serum IgA level remains low, but transformation of lymphocytes with PHA has reverted to normal.

\section{Discussion}

The moderate degrees of thrombocytopenia, neutropenia, and, less frequently, eosinophilia and thrombocytosis which may occur shortly after the initiation of D-penicillamine therapy are rarely severe enough to warrant withdrawal of the drug (Walshe, 1963; Jaffe, 1965; Fawcett et al, 1966; Deiss et al, 1971; Multi-Centre Trial Group, 1973). Agranulocytosis, which is observed more often in patients with rheumatoid arthritis than Wilson's disease, is usually reversible on cessation of the drug (Payne and Cahill, 1969; Golding et al, 1970; Lièvre et al, 1971), although the outcome may be fatal (Corcos et 
al, 1964). Aplastic anaemia is a rare development, usually during the first year of therapy (Bird, 1974; Cramér et al, 1974) and, as with the other haematological effects of D-penicillamine, the reaction appears to be idiosyncratic rather than cytotoxic. Pyridoxine antagonism may be demonstrated in patients on D-penicillamine (Jaffe et al, 1964) and pre-existing pyridoxine deficiency may be exacerbated (Swaiman and Milstein, 1970). However, the antipyridoxine activity of the drug is slight and does not appear to cause clinical signs of deficiency or anaemia. It has been shown that the chelating action of the drug does not influence the serum iron concentration (Walshe and Patston, 1965), although deficiency may develop as the result of variceal haemorrhage from portal hypertension or following haematuria from glomerulonephritis, which is a rare adverse reaction to $D$-penicillamine therapy (Sternlieb et al, 1975). Finally, patients on the drug may develop a lupus-like syndrome with positive tests for antinuclear factor and LE cells. Haematological abnormalities, apart from those due to alimentary blood loss, may occasionally be observed in untreated cases of Wilson's disease. Intermittent haemolytic episodes may frequently pass unrecognized or precede other manifestations of the disease (McIntyre et al, 1967; Deiss et al, 1970; Iser et al, 1974), and pancytopenia has also been reported (Heinrich and Kaltenbach, 1965).

The development of anaemia, in this case, appeared to correspond with an increase in the dose of D-penicillamine and a change to the base form of the drug after 14 years' treatment without any adverse reaction on the hydrochloride. Within 10 weeks of this change, the patient was symptomatic and by 16 weeks the haemoglobin had fallen to $4 \mathrm{~g} / \mathrm{dl}$. Dpenicillamine induced red cell aplasia was considered in view of the absent reticulocyte response and after investigations had excluded blood loss, haemolysis, a lupus-like reaction, and deficiencies of folate, vitamin $B_{12}$, and pyridoxine. No other drugs or potential marrow suppressive agents had been taken by the patient.

Pure red cell aplasia has been described following viral infections, complicating haemolytic anaemia and uraemia and with riboflavin deficiency in children with kwashiorkor. Many drugs and chemicals have also been implicated, but, in most cases, withdrawal of the agent resulted in remission (Mitchell, 1973). Immunological abnormalities have been observed in some cases in association with a thymoma and an IgG autoantibody directed against the patient's erythroblasts (Krantz, 1974). In the present study, D-penicillamine produced equal inhibition of ${ }^{59} \mathrm{Fe}$ incorporation into erythroblast haem of both the patient and control marrows. The drug did not cause lymphocyte transformation and although a diminished response to PHA was observed during the period of red cell aplasia, the significance of this is uncertain with regard to pathogenesis. The mechanism of drug toxicity thus remains undetermined.

The presence of substantial numbers of red cell precursors in the bone marrow was surprising in view of the low reticulocyte count and severe anaemia. It may be explained by patchy loss of erythropoiesis in the marrow which resulted in a biopsy sampling error. It is also possible that erythroblast development was inhibited at a relatively late stage. Before ferrokinetic studies or ${ }^{52} \mathrm{Fe}$ marrow scans could be performed, however, marrow recovery occurred. The reticulocyte count rose three weeks after the cessation of D-penicillamine, and a normal haemoglobin level was achieved within 10 weeks. As a permanent red cell aplasia may well have resulted from the reintroduction of D-penicillamine, administration of the alternative chelating agent, triethylenetetramine dihydrochloride (Walshe, 1969), was begun and has been continued for over 12 months with the maintenance of a normal haemoglobin concentration and adequate urinary copper excretion.

JLG is supported by a Fellowship from the Wellcome Trust. The authors gratefully acknowledge Dr A. Hamlyn, clinical registrar, Mr B. Baker, Manufacturing Pharmacy, Royal Free Hospital, for the preparation of Trien, and Dr J. M. Walshe, Cambridge, for testing the purity of initial samples. We also wish to acknowledge Dr J. M. Goldman, Royal Postgraduate Medical School, for in vitro bone marrow cultures.

\section{References}

Bird, E. D. (1974). Aplastic anaemia following penicillamine Postgrad. med. J., 50, Suppl. 2, pp. 73-74.

Corcos. J. M., Soler-Bechara, J., Mayer, K.. Freyberg, R. H., Goldstein, R., and Jaffe, I. (1964). Neutrophilic agranulo- 음 cytosis during administration of penicillamine. J. Amer. med. Ass., 189, 265-268.

Cramér, K., Golding, J. R., Jaffe, I. A., Moynahan, E. J., 方 Scheinberg, I. H., Schnack H., and Stephens, A. D. (1974). N Round table discussion-Proper use of penicillamine. S Postgrad. med.J., 50, Suppl. 2, pp. 80-83.

Das, K. C. and Hoffbrand, A. V. (1970). Lymphocyte trans- ㅇ formation in megaloblastic anaemia, morphology and $\omega$ DNA synthesis. Brit. J. Haemat., 19, 459-468.

Deiss, A., Lee, G. R., and Cartwright, G. E. (1970). Hemolytic anaemia in Wilson's disease. Ann. intern. Med., 73, 413-418.

Deiss, A., Lynch, R. E., Lee, G. R., and Cartwright, G. E. $\stackrel{\oplus}{+}$ (1971). Long-term therapy of Wilson's disease. Ann. T intern. Med., 75, 57-65.

Dixon, H. B. F., Gibbs, K., and Walshe, J. M. (1972). Pre- $\frac{\vec{D}}{\mathbb{D}}$ paration of triethylenetetramine dihydrochloride for the $\frac{\cap}{\Phi}$ treatment of Wilson's disease. (Letter). Lancet. 1, 853. 
Fawcett, N. P., Nyham, W. L., and Anderson, W. W. (1966). Thrombocytosis during treatment of cystinuria with penicillamine. (Abstr.) J. Pediat., 69, 976-977.

Golding, J. R., Wilson, J. V., and Day, A. T. (1970). Observations on the treatment of rheumatoid disease with penicillamine. Postgrad. med. J., 46, 599-605.

Heinrich, F. and Kaltenbach, M. (1965). Morbus Wilson unter dem Bild einer Panhämozytopenie. Med. Klin., 60, 499-502.

Iser, J. H., Stevens, B. J., Stening, G. F., Hurley, T. H., and Smallwood, R. A. (1974). Hemolytic anemia of Wilson's disease. Gastroenterology, 67, 290-293.

Jaffe, I. A. (1965). The effect of penicillamine on the laboratory parameters in rheumatoid arthritis. Arthr. and Rheum., 8, 1064-1079.

Jaffe, I. A., Altman, K., and Merryman, P. (1964). The antipyridoxine effect of penicillamine in man. J. clin. Invest., 43, 1869-1873.

Krantz, S. B. (1974). Pure red-cell aplasia. New Engl. J. Med., 291, 345-350.

Krantz, S. B., Gallien-Lartigue, O., and Goldwasser, E. (1963). The effect of erythropoietin upon heme synthesis by marrow cells in vitro. J. biol. Chem., 238, 4085-4089.

Lièvre, J. A., Camus, J. P., Bénichou, C., Guillien, P., and Crouzet, J. (1971). Traitement de la polyarthrite rheumatóide commune par la D-pénicillamine. Ann. Méd. interne (Paris), 122, 655-662.
McIntyre, N., Clink, H. M., Levi, A. J., Cumings, J. N., and Sherlock, S. (1967). Hemolytic anemia in Wilson's disease. New Engl. J. Med., 276, 439-444.

Mitchell, A. B. S. (1973). The pathogenesis of acquired pure red cell aplasia. Brit. J. Hosp. Med., 9, 605-608.

Multi-Centre Trial Group (1973). Controlled trial of D(-) penicillamine in severe rheumatoid arthritis. Lancet, 1, 275280.

Payne, R. W. and Cahill, C. L. (1969). Therapeutic studies of D-penicillamine in the treatment of rheumatoid arthritis. J. Okla. med. Ass., 62, 487-491.

Pike, B. L. and Robinson, W. A. (1970). Human bone marrow colony growth in agar-gel. J. cell Comp. Physiol., 76, 77-84.

Sternlieb, I., Bennett, B., and Scheinberg, I. H. (1975). DPenicillamine induced Goodpasture's syndrome in Wilson's disease. Ann. intern. Med., 82, 673-676.

Swaiman, K. F. and Milstein, J. M. (1970). Pyridoxine dependency and penicillamine. Neurology, 20, 78-81.

Walshe, J. M. (1956). Penicillamine, a new oral therapy for Wilson's disease. Amer. J. Med., 21, 487-495.

Walshe, J. M. (1963). Penicillamine. Practitioner, 191, 789795.

Walshe, J. M. (1969). Management of penicillamine nephropathy in Wilson's disease: a new chelating agent. Lancet, 2, 1401-1402.

Walshe, J. M. and Patston, V. (1965). Effect of penicillamine on serum iron. Arch. Dis. Childh., 40, 651-653. 